\title{
Sebaran Lokasi Peneluran Penyu Hijau (Chelonia mydas) di Pulau Sangalaki Kepulauan Derawan Kabupaten Berau
}

\section{Distribution of Nesting Site of Green Turtel (Chelonia mydas) in Sangalaki Island of Derawan Islands, Berau District}

\author{
Andi Ibrahim, Djumanto* \& Namastra Probosunu \\ Departemen Perikanan, Fakultas Pertanian, Universitas Gadjah Mada \\ Jln. Flora Bulaksumur, Yogyakarta 55281 \\ *Penulis untuk korespondensi, e-mail: lely4192@yahoo.com
}

\begin{abstract}
Abstrak
Populasi penyu hijau (Chelonia mydas) yang bertelur di kawasan konservasi kepulauan Derawan semakin menurun disebabkan oleh berbagai faktor. Penelitian ini bertujuan untuk mengetahui jumlah peneluran tiap induk penyu hijau dan korelasinya terhadap naungan, lebar pantai berpasir dan fase bulan. Penelitian ini dilakukan dari tanggal 24 Januari sampai 31 Maret 2015 di Pulau Sangalaki. Pengamatan induk bertelur dilakukan dengan menyusur pantai tiap malam untuk menemukan induk yang sedang bertelur. Sarang yang berisi telur diberi tanda untuk penggalian, pengambilan telur, dan pengukuran kondisi lingkungan. Kondisi lingkungan yang diukur meliputi kedalaman sarang, suhu substrat, jarak sarang terhadap naungan dan garis pantai saat surut terendah. Analisis data dilakukan secara deskriptif terhadap jumlah telur dan parameter lingkungan. Hasil penelitian menunjukkan rerata jumlah telur tiap sarang sebanyak 97 butir dengan kisaran 45-127 butir, ukuran panjang karapas $96 \mathrm{~cm}$ dengan kisaran 86-107 cm, rerata kedalaman sarang $73 \mathrm{~cm}$ dengan kisaran 56-87 cm. Semakin banyak telur yang akan dikeluarkan maka penggalian sarang semakin dalam. Tidak ada korelasi antara panjang karapas dengan jumlah telur yang dikeluarkan. Jumlah rerata induk penyu hijau yang bertelur di Pulau Sangalaki adalah 486 ekor/bulan dengan kisaran 168-1085 ekor/bulan. Musim barat dan timur mempengaruhi frekuensi peneluran. Frekuensi peneluran terjadi sepanjang tahun dan frekuensi peneluran paling tinggi terjadi pada bulan Agustus yang bertepatan dengan puncak musim Timur. Frekuensi peneluran pada musim Timur empat kali lebih banyak daripada saat musim Barat. Frekuensi pendaratan penyu hijau tidak dipengaruhi oleh fase bulan. Berdasarkan lokasi penyu hijau bertelur, pantai yang banyak dipilih untuk lokasi bertelur terdapat di sebelah barat laut, timur laut dan selatan Pulau Sangalaki. Sarang penyu hijau lebih banyak ditemukan pada daerah naungan vegetasi (64\%) daripada daerah pasir terbuka (36\%).
\end{abstract}

Kata kunci: Musim bertelur, penyu hijau, pulau sangalaki

\begin{abstract}
Population of green turtle (Chelonia mydas) that laid their eggs in the Derawan Islands conservation area was declined due to various factors. The aim of this study was to determine the number of egg that was laid down into the nest for each green turtle parent and its correlation to shade, sandy beach width, and moon phase. The study was conducted from 24 January to 31 March 2015 in the Sangalaki Island. The observation of the broods stock was done by walking down the beach in the night to find out the broodstock that laid the eggs and counted the number. A sign was given to the nest of broodstock that finished laying the eggs. On the following day, nest excavation, egg collection, and the environmental measurement were conducted. Environmental conditions were measured include the depth of the nest, substrate temperature, the distance of the nest site to the shading trees and the border line of lowest tide. Data analysis was done descriptively by counting the number of eggs and environmental parameters. The results show that the average number of egg per nest was 97 items with the range of $45-127$ items, the length of the carapace was $96 \mathrm{~cm}$ with a range of $86-107$ $\mathrm{cm}$, the average depth of the nest hole was $73 \mathrm{~cm}$ with a range of $56-87 \mathrm{~cm}$. Broods stock of green turtle that laid more eggs would dig nest hole deeper, but there was no correlation between the carapace length and the number of the laid eggs. The average number of green turtle broods stock that lay eggs in the Sangalaki Island was 486 individual/ month with the range of 168 - 1085 individu/month. The west and east seasons affect the frequency of nesting and the laid eggs. The frequency of spawning occured throughout the year and the highest spawning frequency occured in August which coincides with the peak of the East Season. The frequency of spawning during the East Season was four times higher than during the West season. The frequency of green turtle landing was not affected by the lunar phase. Based on the location of laying egg, the beaches that were selected for laying egg are located in the northwest, northeast, and south parts of the Sangalaki Island. The Green turtle nests were commonly found in the vegetation shading areas (64\%) than open sand areas (36\%).
\end{abstract}

Key words: Egg laying season, green turtles, sangalaki island 


\section{Latar Belakang}

Penyu hijau (Chelonia mydas) merupakan hewan amfibi yang membutuhkan habitat khusus untuk berkembang biak, membutuhkan kawasan pantai yang spesifik untuk menyimpan dan mengerami telurnya, mempunyai umur yang relatif panjang (Adnyana \& Hitipeuw, 2009; Ahmad et al., 2006). Masa reproduksi induk betina penyu sangat terbatas, jumlah telur yang dihasilkan tiap induk penyu berkisar 60-120 butir, daya tetas alami sekitar $50 \%$ dan tingkat kelulushidupan tukik (anakan penyu) rendah (Budiastuti, 2012), menyebabkan populasi penyu hijau cenderung menurun, sehingga perlu campur tangan semua pihak untuk melindungi populasinya (Ali et al., 2005). Pemerintah Indonesia telah menerbitkan undang-undang untuk melindungi keberadaan penyu, yaitu Undang-Undang nomor 5 tahun 1990 dan UU no. 31 tahun 2004. Indonesia sebagai negara kepulauan yang wilayahnya memanjang di garis khatulistiwa memiliki kawasan perairan yang sangat luas, terdiri padang lamun dan terumbu karang, serta tersedia berbagai jenis alga, kekerangan dan krustase yang menjadi makanan utama penyu (Akira et al., 2012).

Penyu yang ditemukan di Indonesia ada 6 spesies, yaitu penyu hijau (Chelonia mydas), penyu sisik (Eretmochelys imbricata), penyu lekang (Lepidochelys olivaceae), penyu belimbing (Dermochelys coriaceae), penyu tempayan (Caretta caretta) dan penyu pipih (Natator depresus) (Taylor et al, 2006, Pritchard \& Mortimer, 1999). Keberadaan penyu telah lama terancam, baik oleh proses alam maupun kegiatan manusia yang membahayakan populasinya secara langsung maupun tidak langsung (Susilowati, 2002). Kerusakan habitat peneluran, daerah pertumbuhan dan pembesaran serta polusi lingkungan laut menyebabkan populasi penyu terus menurun. Faktor lainnya adalah pemanfaatan penyu dan pengambilan telurnya yang berlebihan menyebabkan populasi penyu menurun sangat cepat. Penurunan populasi penyu dapat menyebabkan ketidakseimbangan ekosistem laut, sehingga badan perlindungan alam dunia (IUCN) memasukkan penyu ke dalam daftar merah (red list) dengan kategori terancam punah (Endangered) dan kritis (Critically endangered), sedangkan konvensi perdagangan internasional untuk spesies flora dan satwa liar rawan punah (CITES) mengkategorikan semua jenis penyu ke dalam Appendix I, yang melarang terhadap perdagangan internasional penyu dan turunannya untuk tujuan komersil kecuali hasil pengembangbiakan. Status perlindungan terhadap penyu diharapkan dapat mempertahankan dan meningkatkan populasi penyu di dunia (Hirth, 1971; Dick, 2005).

Penyu hijau banyak ditemukan di wilayah perairan
Kepulauan Derawan Kabupaten Berau. Pulau-pulau yang diketahui menjadi habitat bertelur penyu hijau di wilayah Kepulauan Derawan yaitu Pulau Derawan, Sangalaki, Semama, Sambit, Bilang-bilangan, Mataha dan Balikukup. Pulau Sangalaki adalah pulau dengan kepadatan bertelur penyu tertinggi, menyumbang lebih dari $30 \%$ dari total keseluruhan populasi penyu bertelur di Kabupaten Berau (Adnyana et al., 2007).

Penyu membutuhkan pantai berpasir untuk membuat sarang dan meletakkan telurnya. Kawasan Konservasi Laut Kepulauan Derawan di Kalimantan Timur memiliki beberapa pulau yang menjadi tempat paforit penyu untuk menetaskan telurnya. Sekeliling Pulau Sangalaki merupakan pantai berpasir yang menjadi habitat peneluran penyu (Machfudhi, 2014). Pulau Sangalaki memiliki panjang pantai sekitar 1.500 meter merupakan salah satu lokasi utama dari habitat peneluran penyu hijau, memiliki luas \pm 15 hektar. Pulau Sangalaki memiliki pantai yang landai, lebar dan butiran pasirnya halus, sehingga sesuai untuk peneluran penyu (Mukminin, 2002). Agar pengelolaan suatu kawasan konservasi berhasil, maka berbagai data dan informasi sangat dibutuhkan, sebagai dasar penetapan strategi dan kebijakan. Salah satu informasi tersebut adalah lokasi dan pola peneluran penyu hijau. Penelitian ini bertujuan untuk mengetahui produksi telur, frekuensi peneluran dan kesukaan habitat tempat peletakan telur bagi penyu hijau (Chelonia mydas) di pantai Pulau Sangalaki yang dikaitkan dengan pengaruh musim dan fase bulan.

\section{Metode}

\section{Lokasi Penelitian}

Lokasi penelitian berada di Pulau Sangalaki, Kepulauan Derawan, Kabupaten Berau, Kalimantan Timur yang secara geografis terletak pada posisi $02^{\circ}$ 5' $02^{\prime \prime}-02^{\circ} 5^{\prime} 17^{\prime \prime}$ LU dan $118^{\circ} 23^{\prime} 49^{\prime \prime}-118^{\circ} 24^{\prime} 08^{\prime \prime}$ BT. Peta lokasi penelitian disajikan pada Gambar 3.1. Penelitian dilakukan pada Januari - Maret 2015 di Pulau Sangalaki. Pengamatan penyu hijau dilakukan di 15 stasiun sepanjang garis pantai Pulau Sangalaki.

Pulau Sangalaki memiliki pantai sepanjang 1,61 km, yang hampir seluruhnya berupa pantai pasir, sehingga menjadi habitat utama bagi penyu untuk bersarang. Agar pengamatan aktivitas peneluran lebih efisien dan efektif, maka garis pantai dibagi ke dalam 15 stasiun, kemudian stasiun tersebut kelompokkan berdasarkan letak arah mata angin. Rerata panjang garis pantai tiap stasiun adalah $100 \mathrm{~m}$.

Peralatan yang digunakan terdiri atas pita berskala dengan panjang $150 \mathrm{~cm}$ untuk mengukur panjang karapas penyu, tongkat stainless steel dengan panjang $100 \mathrm{~cm}$ untuk mencari posisi sarang penyu 


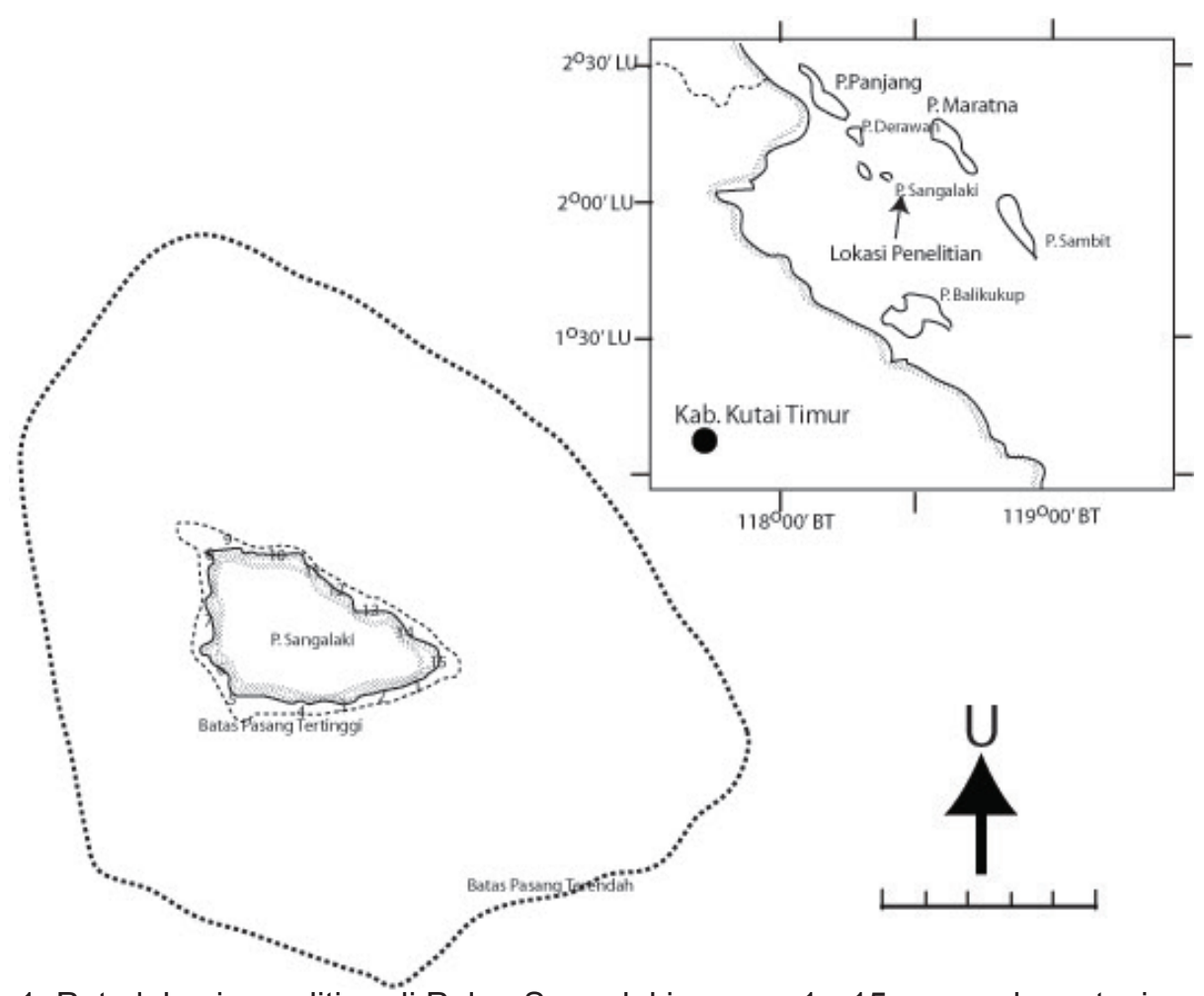

Gambar 1. Peta lokasi penelitian di Pulau Sangalaki, nomor 1 - 15 merupakan stasiun pengamatan.

hijau, Global Positioning System (GPS) untuk mengetahui posisi koordinat stasiun pantai; roll meter dengan panjang 100 meter untuk mengukur panjang garis pantai dan jarak sarang dari garis pantai dan naungan terdekat; senter untuk penerangan saat pengambilan data di malam hari. Jenis data yang dikumpulkan terdiri atas panjang karapas penyu hijau, jumlah telur tiap sarang, kedalaman sarang, posisi sarang pada tiap stasiun stasiun, panjang pantai, jarak sarang dari pepohonan atau naungan, dan jarak sarang dari pasang tertinggi.

Panjang karapas diukur menggunakan pita berskala mulai dari belakang kepala hingga bagian ujung belakang karapas. Jumlah teur tiap sarang dilakukan dengan menghitung telur yang dikeluarkan penyu betina saat sedang mengeluarkan telurnya ke dalam sarang. Jika saat penyu ditemukan sudah selesai bertelur, maka sarang digali kemudian telur diangkat dari sarang untuk dihitung. Kedalaman sarang diukur dari permukaan hingga dasar sarang. Kedalaman diukur dengan menggunakan pita berskala, dilakukan setelah semua telur diangkat dari sarang.

Posisi koordinat stasiun dicatat berdasarkan data koordinat yang tersaji pada layar GPS. Penetapan titik koordinat dilakukan dengan meletakkan GPS diatas titik tengah dari stasiun. Posisi sarang pada tiap stasiun ditetapkan menggunakan GPS. Jarak sarang diukur dari titik pusat tiap sarang yang ditemukan telurnya hingga ke batas pepohonan dan batas pasang tertinggi. Jarak tersebut diukur dengan menggunakan roll meter. Panjang pantai tiap stasiun diukur menggunakan roll meter, dilakukan pada garis pasang tertinggi memanjang sejajar dengan garis pantai dari ujung stasiun 1 hingga ujung stasiun 15.

\section{Analisis Data}

Data dianalisis secara deskriptif meliputi sebaran panjang karapas, jumlah telur dan kedalaman sarang. Selain itu, analisis data dilakukan untuk mengetahui korelasi antara jumlah telur dengan panjang karapas dan kedalaman sarang.

Data sebaran lokasi peneluran penyu dianalisis untuk mengetahui lokasi yang menjadi tujuan utama peneluran. Analisis dilakukan berdasarkan data koordinat stasiun dan jumlah induk penyu yang bertelur. Sebaran lokasi peneluran diperoleh dengan melakukan ploting jumlah induk yang bersarang terhadap posisi sarang.

Data distribusi peneluran berdasarkan fase bulan atau musim dianalisis dengan menghubungkan frekuensi peneluran penyu terhadap fase bulan.

\section{Hasil}

Panjang Karapas dan Jumlah Telur Jumlah individu induk penyu yang mendarat sebanyak 50 ekor. Induk penyu yang diamati adalah penyu hijau yang bertelur, sehingga seluruh induk yang dijadikan 
sampel berjenis kelamin betina. Sebaran panjang karapas dan jumlah telur penyu hijau yang teramati dapat dilihat pada Gambar 2.

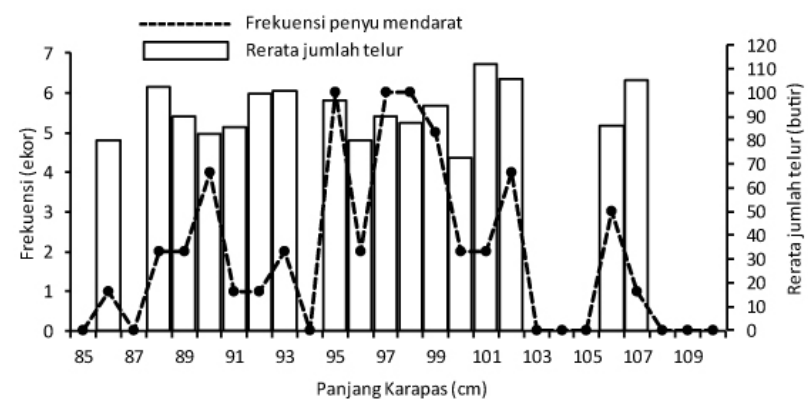

Gambar 2. Distribusi frekuensi panjang karapas dan rerata jumlah telur penyu hijau.

Panjang karapas penyu hijau yang mendarat untuk bertelur berkisar antara 86 hingga $107 \mathrm{~cm}$. Induk penyu hijau betina paling banyak ditemukan pada ukuran panjang karapas 95, 97 dan $98 \mathrm{~cm}$ (masingmasing 6 ekor) dan paling sedikit pada ukuran 86 dan $107 \mathrm{~cm}$. Jumlah telur yang dikeluarkan tiap induk betina berkisar antara 45 - 127 butir, sedangkan rerata jumlah telur berdasarkan frekuensi penyu hijau tiap ukuran panjang karapas berkisar antara 74 - 114 butir.

\section{Kedalaman Sarang}

Jumlah telur yang dikeluarkan tiap induk penyu betina tiap sarang bervariasi. Semakin besar ukuran induk betina, akan menghasilkan jumlah telur semakin banyak dan sarang yang dibuat semakin dalam. Sebaran jumlah telur tiap ukuran panjang karapas dapat dilihat pada Gambar 3.

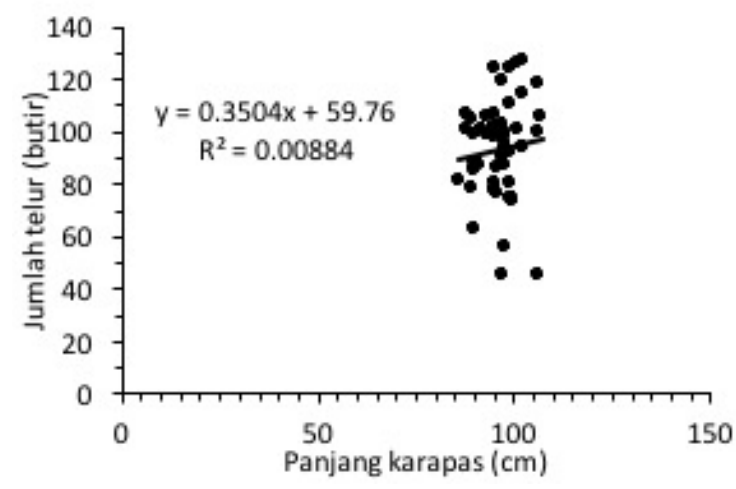

Gambar 3. Sebaran jumlah telur pada tiap panjang karapas induk betina penyu hijau.

Semakin panjang ukuran karapas induk betina, maka jumlah telur yang dikeluarkan semakin banyak. Hubungan panjang karapas dan kemampuan memproduksi telur membentuk persamaan $\mathrm{y}=$ $0,3504 x+59,76$ dan koefisien determinasi sebesar 0,0088 . Korelasi (r) antara panjang karapas dengan jumlah telur sebesar 0,0938 menunjukkan hasil yang positif namun sangat lemah.
Hasil pengukuran terhadap kedalaman sarang menunjukkan kisaran kedalaman sarang yang dibuat oleh induk penyu betina adalah $50-87 \mathrm{~cm}$. Sebaran ukuran kedalaman sarang disajikan pada gambar 4 .

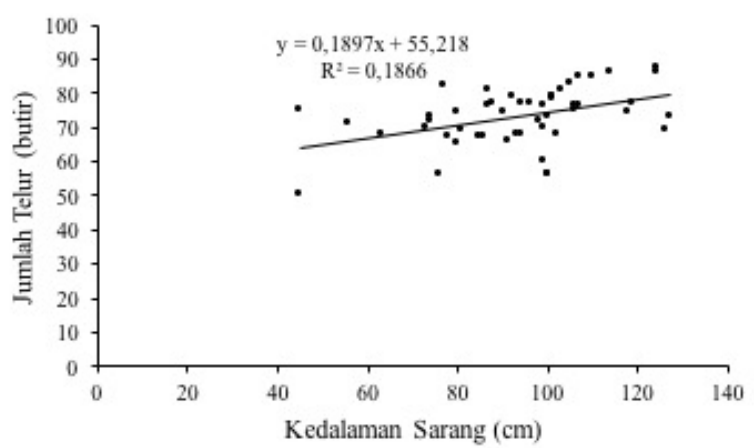

Gambar 4. Sebaran jumlah telur pada berbagai kedalaman sarang.

Semakin besar ukuran panjang karapas akan semakin mampu membuat sarang lebih dalam dan menghasilkan telur lebih banyak. Jumlah telur dan kedalaman sarang membentuk hubungan dengan persamaan $y=0,1897 x+55,218$ dan koefisien determinasi $\left(R^{2}\right) 0,1866$. Semakin banyak telur yang dihasilkan berkolerasi positif terhadap kedalaman sarang.

\section{Sebaran lokasi Peneluran}

Lokasi bersarang penyu hijau di Pulau Sangalaki tersebar di sekeliling pantai pulau ini. Pantai peneluran di wilayah ini dibagi ke dalam empat wilayah berdasarkan arah mata angin. Pantai peneluran di tenggara memiliki karakteristik pantai dengan lebar pantai yang potensial untuk bertelur penyu sekitar 100 meter atau paling lebar dibandingkan dengan pantai peneluran lainnya. Tipe vegetasi yang mendominasi di lokasi ini adalah tipe pohon dengan ukuran besar namun tidak padat. Pantai peneluran di barat daya memiliki karakteristik pantai dengan padat vegetasi dan lebar pantai yang tidak terlalu lebar. Lebar pantai yang potensial sebagai lokasi peneluran yaitu sepanjang 10 meter dari garis pasang tertinggi, namun stasiun 6 memiliki kondisi yang berbeda. Batas pasang tertinggi di stasiun 6 berada di batas daratan tempat tumbuhnya vegetasi, sehingga lebar pantai peneluran hanya beberapa puluh sentimeter saja. Pantai peneluran daerah barat laut memiliki karakteristik vegetasi cukup padat dengan lebar pantai yang berpotensi sebagai lokasi peneluran sekitar 10 - 12 meter dari batas pasang tertinggi. Hampir keseluruhan daerah pantai peneluran ternaungi oleh vegetasi berukuran besar. Karakteristik pantai peneluran di posisi timur laut didominasi oleh vegetasi dengan tipe semak dan perdu. Lebar pantai di lokasi ini sama seperti di lokasi pantai peneluran di posisi barat daya yaitu 10 meter dari garis pasang 
tertinggi.

Penyu hijau yang ditemukan selama penelitian membuat sarang di zona supratidal. Di zona ini sebagian besar penyu hijau membuat sarang di bawah naungan vegetasi pantai dan sisanya dibuat pada daerah pasir terbuka di dekat vegetasi pantai. Frekuensi penyu hijau yang membuat sarang di bawah naungan vegetasi dan di pasir terbuka dapat dilihat pada Gambar 5.

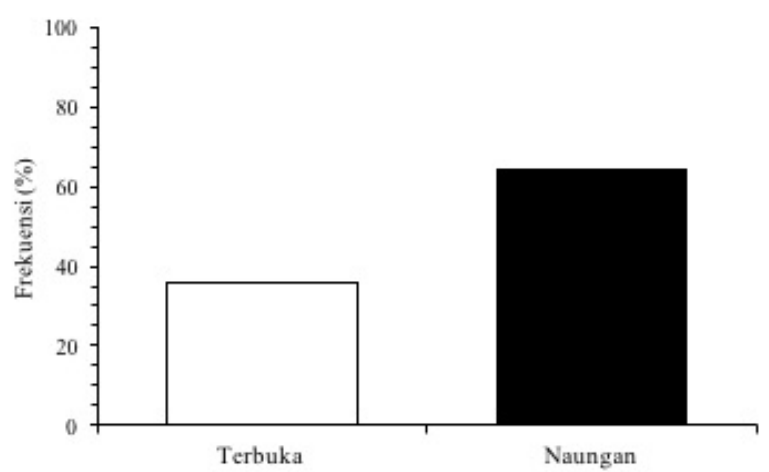

Gambar 5. Distribusi frekuensi lokasi bersarang penyu hijau.

Penyu hijau di Pulau Sangalaki lebih banyak membuat sarang pada daerah yang dinaungi oleh vegetasi daripada di daerah pasir terbuka. Sebanyak $64 \%$ sarang ditemukan di daerah yang dinaungi vegetasi dengan total cacah 32 sarang, sedangkan di daerah pasir terbuka ditemukan sebanyak $36 \%$ sarang dengan total cacah sebesar 18 sarang.

\section{Posisi Sarang}

Berdasarkan jarak sarang dari batas pasang tertinggi dan batas pepohonan, penyu hijau di Pulau Sangalaki, maka induk penyu cenderung membuat sarang agak jauh dari garis pantai hingga ke batas zona terestrial, yaitu daerah yang merupakan batas pepohonan dan merupakan batas akhir penyu hijau mampu menggali sarangnya. Jarak lokasi sarang yang ditemukan terhadap batas pasang tertinggi dan batas pepohonan dapat dilihat pada Gambar 6 .

Penyu hijau memiliki strategi alami untuk meletakkan telur-telurnya. Strategi yang digunakan adalah mencari lokasi yang jauh dari paparan pasang air laut dan dekat batas pepohonan. Kisaran jarak sarang dari batas pepohonan yaitu antara 1 - $8 \mathrm{~m}$. Sebanyak 12 sarang ditemukan pada jarak 2 - 4 m. Sarang yang ditemukan pada batas pasang tertinggi berada pada jarak antara 2 - 30 meter. Sebanyak 8 sarang ditemukan pada jarak 9 meter dari batas pasang tertinggi dan sebanyak 9 sarang ditemukan pada jarak 10 meter dari batas pasang tertinggi. Ditemukan 3 sarang yang berada pada jarak 5, 7, 8, 15, 16 dan 17 meter dari batas pasang tertinggi. Lokasi sarang penyu untuk bertelur banyak ditemukan pada kisaran jarak 5 - 17 meter dari batas pasang tertinggi.

Frekuensi pendaratan berdasarkan Pengaruh Fase Bulan

Pola pasang surut perairan laut dan cahaya bulan mempengaruhi tingkah laku pendaratan penyu untuk bertelur. Pengaruh bulan terhadap tingkah laku penyu hijau untuk naik ke daratan dan bertelur terbagi menjadi dua, yaitu hubungannya dengan pasang surut dan pengaruh cahaya bulan. Frekuensi penyu hijau yang mendarat pada kondisi fase bulan yang berbeda disajikan pada Gambar 7.

Penyu hijau yang mendarat pada bulan Januari hingga April, ditemukan sebanyak 785 ekor. Sebanyak 195 ekor mendarat saat fase bulan purnama; 200 ekor mendarat saat fase bulan kuartal ketiga; 173 ekor mendarat saat fase bulan gelap; 217 mendarat saat fase bulan kuartal pertama. Pendaratan penyu hijau

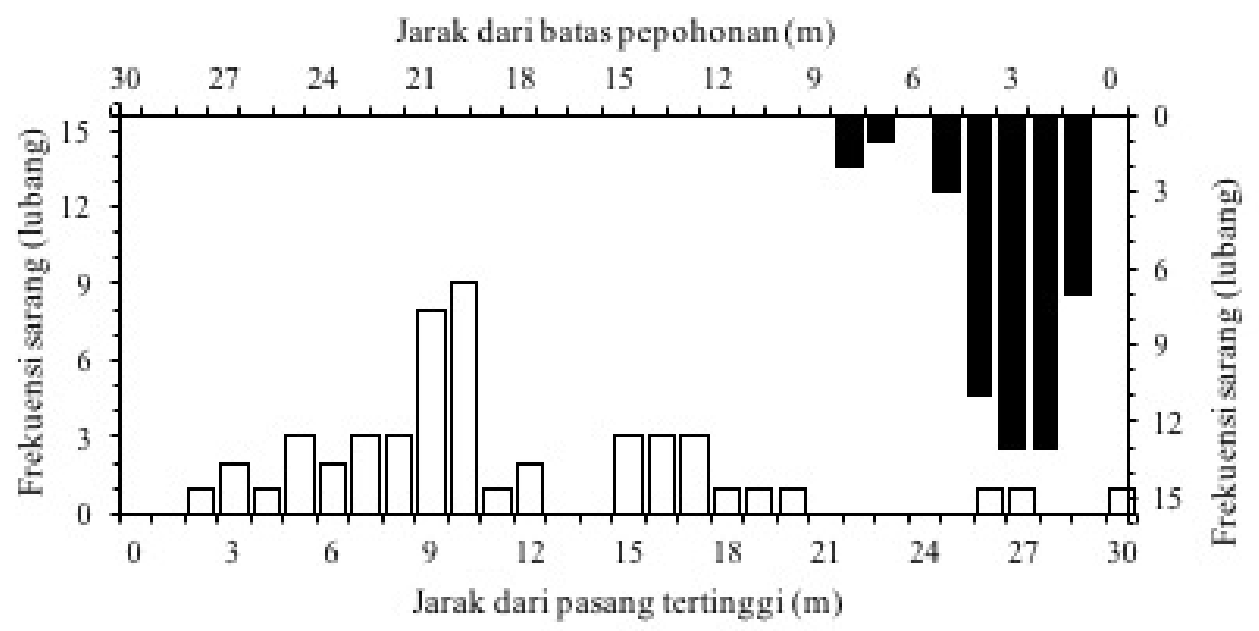

Gambar 6. Distribusi frekuensi jarak sarang dari batas pepohonan dan jarak sarang dari batas pasang tertinggi. 


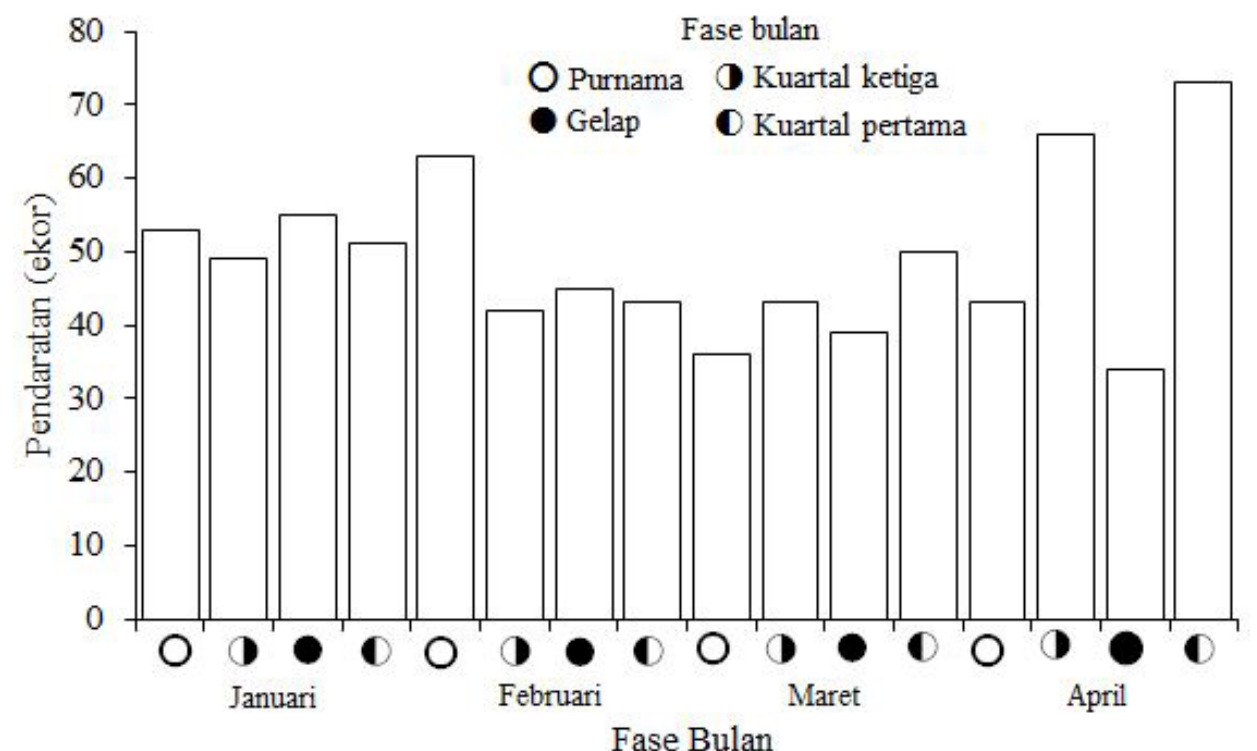

Gambar 7. Pola peneluran penyu hijau di Pulau Sangalaki terhadap fase bulan.

untuk bertelur cenderung lebih banyak terjadi di malam hari saat fase bulan kuartal pertama.

\section{Pembahasan}

Ukuran panjang karapas induk penyu hijau yang mendarat dan membuat sarang di pulau Sangalaki bervariasi, panjang karapas berkisar antara 86 - 107 $\mathrm{cm}$ dan kedalaman sarang yang dibuat berkisar $50-87 \mathrm{~cm}$.Kisaran panjang karapas penyu hijau di Pantai Alagadi Siprus memiliki kisaran $77-106 \mathrm{~cm}$ (Broderick et al., 2003), sedangkan pengamatan Nuitja (1992) terhadap panjang karapas induk penyu hijau yang bertelur di Indonesia didominasi oleh ukuran $90-102 \mathrm{~cm}$. Ukuran penyu hijau yang membuat sarang di Pulau Sangalaki lebih beragam. Apabila ukuran panjang karapas induk penyu menunjukkan umurnya dan penyu yang lebih besar memiliki umur lebih tua (Sparre \& Venema, 1998), maka penyu yang berukuran besar telah bertelur beberapa kali, sedangkan penyu yang paling kecil diduga baru pertama kali bertelur.

Jumlah telur yang dikeluarkan induk betina penyu hijau pada ukuran panjang yang sama relatif sama, sedangkan semakin besar ukuran panjang karapas cenderung semakin banyak. Induk betina yang memiliki ukuran karapas semakin panjang, maka gonadnya mampu mengandung butiran telur semakin banyak. Perbedaan jumlah telur yang dikeluarkan indukan penyu hijau betina pada tiap sarangnya dapat dipengaruhi oleh kandungan gizi makanan yang dikonsumsi penyu. Sedangkan kedalaman sarang yang berbeda dipengaruhi oleh penggalian sarang oleh indukan penyu dan substrat pasir pantai. Induk penyu hijau yang bersarang di Pantai Pangumbahan Sukabumi berkisar antara $59-172 \mathrm{~cm}$ dengan kisaran kedalaman sarang 31,6 - 66,7 cm (Salamsyah, 2004).

Sebaran lokasi peneluran penyu hijau memiliki frekuensi tertinggi pada pantai daerah barat laut, timur laut dan selatan di musim puncak maupun musim terendah peneluran. Tingginya frekuensi peneluran penyu pada daerah tersebut dipengaruhi oleh orientasi penyu saat memilih daerah peneluran. Induk penyu memiliki cara dalam mencari lokasi peneluran, yaitu (1) memanfaatkan air pasang tinggi, sehingga menghemat energi ; (2) memanfaatkan suasana gelap pada daerah terbuka untuk menghindari pemangsa (Anderson, 1958 cit. Nuitja, 1992). Sebelum bergerak ke pantai, penyu mula-mula muncul ke permukaan air laut, selanjutnya penyu berdiam sebentar dan mengamati sekelilingnya. Saat mengamati sekelilingnya penyu mengamati wilayah pantai yang gelap lalu bergerak ke pantai. Pantai di barat laut, timur laut dan selatan memiliki kenampakkan pantai yang bervegetasi rimbun, sehingga pada malam hari menimbulkan suasana yang lebih gelap dibandingkan dengan pantai di bagian lainnya. Suasana gelap menciptakan rasa aman terhadap penyu dari ancaman predator. Selain itu, gangguan berupa batang kayu terdampar dan pohon tumbang tidak terlalu banyak ditemukan pada daerah pantai tersebut dibandingkan dengan pantai di bagian lainnya (Djohan, 2004).

Sebagian besar (64\%) induk penyu hijau membuat sarang pada naungan vegetasi di zona supratidal, sedangkan sarang lainnya berada di daerah bebas naungan vegetasi. Hal tersebut berbeda dengan lokasi peneluran induk penyu di pantai Sukamade, 
sebanyak $24,8 \%$ sarang telur penyu hijau ditemukan berada dibawah naungan pohon dan sebanyak $75,2 \%$ sarang ditemukan di pasir terbuka di depan formasi hutan Pandanus yang masih berada pada daerah supratidal (Nuitja, 1992). Pada penyu belimbing (Dermochelys coriacea), lebih dari 80\% induk penyu belimbing bersarang di pasir terbuka, sisanya bersarang di bawah vegetasi (Kamel \& Mrosovsky, 2004). Pemilihan lokasi bersarang penyu ditentukan berdasarkan karakteristik pantainya, karena penyu datang ke daratan untuk bertelur di berbagai lokasi di sepanjang pantai. Karakteristik pantai peneluran di Pulau Sangalaki yang banyak ditumbuhi vegetasi dengan tipe pertumbuhan pohon dan memiliki ukuran besar di sepanjang pantai, menyebabkan lokasi bersarang penyu lebih dominan ditutupi naungan vegetasi. Disamping itu, pemilihan lokasi bersarang berdasarkan ada tidaknya naungan dapat mempengaruhi penetasan telur. Pada lokasi yang bebas naungan menyebabkan sarang telur akan terpapar intensitas matahari secara langsung dan dapat menyebabkan suhu sarang menjadi lebih panas, sehingga reaksi kimia berlangsung lebih cepat dan masa inkubasi telur penyu lebih pendek (Nuitja, 1992). Jika dihubungkan dengan pemanasan global yang menyebabkan suhu bumi meningkat saat ini, keberadaan sarang pada daerah naungan vegetasi dapat menstabilkan suhu sarang agar tidak terlalu panas. Suhu inkubasi yang terlalu panas $\left(>30^{\circ} \mathrm{C}\right)$ akan menghasilkan lebih banyak penyu betina. Jika semua sarang penyu memiliki suhu yang panas selama masa inkubasi, maka akan menyebabkan populasi penyu betina lebih tinggi dibandingkan dengan populasi penyu jantan, sehingga rasio kelamin penyu dialam tidak seimbang. Hal tersebut dapat mengurangi kesempatan penyu untuk melakukan reproduksi.

Penyu betina memiliki insting untuk meletakkan telur-telurnya pada lokasi yang aman dari jarak air pasang. Penyu memilih lokasi bertelur pada dataran yang landai dan tidak terkena pasang. Menurut Kamel \& Mrosovsky (2004), mayoritas penyu betina lebih suka bersarang di atau sekitar batas pasang tertinggi. Penyu mengurangi risiko disorientasi pada tukik yang menetas dan peningkatan gangguan predator terhadap sarang dan tukik dengan menghindari daerah vegetasi yang padat, tetapi meningkatkan kemungkinan daya tetas yang rendah karena terpapar air pasang. Hal ini seiring dengan hasil studi yang dilakukan terhadap peneluran penyu hijau di Pulau Sangalaki. Seluruh sampel penyu hijau meletakkan telurnya di atas batas pasang tertinggi dan agak jauh dari batas pepohonan.

Faktor yang mempengaruhi pendaratan penyu hijau yakni fase bulan. Adanya air pasang membantu penyu menghemat energi untuk bergerak dari laut ke pantai untuk memulai proses bertelur dan bergerak dari pantai ke laut setelah proses bertelur. Dalam hal ini pengaruh fase bulan terhadap pendaratan penyu berhubungan dengan pasang surut. Pendaratan penyu hijau di Pulau Sangalaki cenderung lebih banyak saat fase bulan kuartal pertama, meskipun tidak ada perbedaan yang nyata antara jumlah pendaratan penyu pada empat fase bulan lainnya (Law, 2009). Pendaratan penyu hijau di Samudera Pasifik bagian timur banyak terjadi pada fase bulan kuartal ketiga. Pada Lepidochelys olivacea di Ghana menunjukkan preferensi pendaratan terjadi saat bulan tidak masuk dalam fase bulan penuh, dengan puncak tertinggi saat fase bulan kuartal ketiga.

\section{Kesimpulan}

Ukuran panjang karapas penyu hijau yang membuat sarang di Pulau Sangalaki berkisar 86 - $107 \mathrm{~cm}$ dengan jumlah telur yang dikeluarkan tiap individu penyu sebanyak 45 - 127 butir. Ukuran panjang karapas tidak mempengaruhi jumlah telur yang dikeluarkan kedalam sarang. Induk betina penyu hijau menggali sarang semakin dalam jika telur yang dihasilkan semakin banyak.

Lokasi peneluran penyu di Pulau Sangalaki banyak ditemui di di sebelah barat laut, timur laut dan selatan yang memiliki vegetasi rimbun, landai dan lebar. Frekuensi pendaratan penyu hijau tidak dipengaruhi oleh siklus bulan, namun penyu hijau cenderung lebih banyak mendarat saat fase bulan kuartal pertama yang bertepatan dengan perbedaan amplitudo pasang paling tinggi.

\section{Saran}

Perlunya dilakukan penetasan telur secara semi alami melalui penempatan sarang telur di bawah naungan vegetasi dan daerah terbuka dengan persentase yang sama untuk mengatur rasio kelamin tukik.

\section{Ucapan Terimakasih}

Penulis mengucapkan terima kasih kepada Koordinator Marine Species Program WWF-Indonesia Ibu Dwi Suprapti dan Koordinator Program Penyu WWF - Indonesia Site Berau Bapak Rusli Andar yang telah memberikan dukungan pendanaan untuk melakukan penelitian di Pulau Sangalaki. Ucapan terima kasih disampaikan kepada Kepala Seksi Konservasi Wilayah 1 Berau yang telah memberikan izin untuk melakukan penelitian di Pulau Sangalaki, kepada Bapak Ketut, dkk. selaku tim konservasi penyu Seksi Konservasi Wilayah 1 Berau yang telah 
memandu dan membantu melakukan penelitian, serta semua pihak yang telah membantu sejak awal hingga selesainya penelitian. Ucapan terimaksih juga disampaikan kepada reviwer yang telah memberi saran dan masukan yang konstruktif untuk kesempurnaan tulisan ini.

\section{Daftar Pustaka}

Adnyana, I.B.W \& C. Hitipeuw. 2009. Panduan Melakukan Pemantauan Populasi Penyu di Pantai Peneluran di Indonesia. WWF-Indonesia Marine Program. Jakarta.

Adnyana, W., L.P. Soede, G. Gearheart \& M. Halim. 2007. Status of green turtle (Chelonia mydas) nesting and foraging populations of Berau, East Kalimantan, Indonesia, including result from tagging and telemetry. Indian Ocean Turtle Newsletter.

Ahmad, A., K.Y. Ku Kassim, T. Zulkifli, M.I. Mahyam \& A.R. Solahudi. 2006. A guide for tagging of sea turtles in the Southeast Asian region. MFRDMD/ $\mathrm{SP} / 11$. Kuala Terengganu, Malaysia. $62 \mathrm{pp}$.

Akira, R., I. N. Wandia \& W.B Adyana. 2012. Komposisi genetik penyu hijau (Chelonia mydas) hasil tangkapan liar dari Nusa Tenggara Barat (Bima dan Teluk Cempi). Indonesia Medicus Veterinus 1(1): 22-36.

Ali, A., K.Y. Ku Kassim, A. R Solahuddin \& T. Zulkifli. 2005. Individual nest site preference of green turtle, Chelonia mydas, on mak kepit beach and its relation with hatching emergence success. Marine Fishery Resources Development and Management Department. pp. 45-49

Broderick, A.C., F. Glen, B. J. Godley \& G. C. Hays. 2003. Variation in reproductive output of marine turtles. J. Exp. Mar. Biol. Ecol. (288): 95-109.

Budiastuti, A. R. 2012. Pengaruh Beda Waktu Pengambilan Telur Terhadap Daya Tetas Telur Penyu Hijau (Chelonia mydas) di Pulau Mataha, Kepulauan Derawan, Kalimantan Timur. Jurusan Teknologi Pengelolaan Sumberdaya Perairan. Sekolah Tinggi Perikanan. Jakarta.

Dick, B. 2005. Green Sea Turtle (Chelonia mydas). Pro Tempore Secretariat of the Inter-American Convention for the Protection and Conservation of Sea Turtles (IAC). San Jose. Costa Rica.

Djohan, T. S. 2004. Konservasi Habitat Penyu. Workshop Evaluasi dan Monitoring Kelembagaan Konservasi Penyu. Badan Pengendalian Dampak Lingkungan Daerah. Yogyakarta.
Hirth, H. F. 1971. Synopsis of Biology Data on The Green Turtle, Chelonia mydas (Linnaeus 1758). FAO. Fisheries Synopsis.

Kamel, S.J. \& N. Mrosovsky. 2004. Nest site selection in leatherbacks, Dermochelys coriacea: individual patterns and their cosequences. Animal Behaviour 68: 357-366.

Law, A. 2009. The Influence of Lunar Phases, Weather nd Tidal Patterns on The Nesting Activity of Adult Female Leatherbacks (Dermochelys coriaceae) in Tobago, West Indies. Division of Environmental and Evolutionary Biology. University of Glasgow. Research report.

Machfudhi, A. 2014. Preferensi Lokasi Bersarang Penyu Hijau (Chelonia mydas) Di Pulau Sangalaki Kalimantan Timur. Fakultas Kehutanan. Universitas Gadjah Mada. Tesis.

Mukminin, A. 2002. Studi Habitat Peneluran Penyu Hijau (Chelonia mydas, L) Di Pulau Sangalaki, Kepulauan Derawan, Kabupaten Berau, Kalimantan Timur. Fakultas Perikanan dan IImu Kelautan. Institut Pertanian Bogor. Skripsi.

Nuitja, I.N.S. 1992. Biologi dan Ekologi Pelestarian Penyu Laut. IPB Press, Bogor.

Pritchard, P.C.H. \& J.A Mortimer. 1999. Taxonomy, External Morphology and Species Identification. Research and Management Techniques for the Conservation of Sea Turtles. No.4.

Salamsyah, I.J. 2004. Analisis Populasi Penyu Hijau (Chelonia mydas, Linnaeus 1758) di Pantai Pangumbahan Kabupaten Sukabumi. Fakultas Perikanan dan IImu Kelautan. Institut Pertanian Bogor. Skripsi.

Sparre, P. \& Venema S.C. 1998. Introduction to Tropical fish stok assessment. Part. 1. Manual. FAO fisheries technical Paper. No. 306.1. Rev. 2. $407 \mathrm{p}$.

Susilowati, T. 2002. Studi Parameter Biofisik Pantai Peneluran Penyu Hijau (Chelonia mydas, L) di Pantai Pangumbahan Sukabumi Jawa Barat. Fakultas Perikanan dan IImu Kelautan. Institut Pertanian Bogor. Skripsi.

Taylor, R., R. Chatto \& J. Woinarski. 2006. Green Turtle (Chelonia mydas). Department of Natural Resources, Evironmental and the Arts. Northern Territory Government. 